\title{
No Evidence of a Major Learning Slide 14 Months into the COVID-19 Pandemic in Denmark
}

\author{
Jesper Fels Birkelund (jfb@soc.ku.dk) \\ Kristian Bernt Karlson (kbk@soc.ku.dk) \\ Department of Sociology, University of Copenhagen
}

November 9, 2021

\begin{abstract}
We study the long-term effects of the COVID-19 pandemic on children's academic performance in Denmark 14 months into the pandemic using nationwide and exceptionally rich data on reading test scores and family background $(\mathrm{N} \approx 200.000$ per year). We find no evidence of any major learning slide. While pupils in grade 8 experienced a three percentile points loss in reading performance, pupils in grades 2 and 4 experienced a learning gain of about five percentile points, possibly resulting from school closures being significantly longer among older (22 weeks) than younger children (eight weeks). Importantly and in contrast to expectations, we find little evidence of widening learning gaps by family background. Still, in grade 8 we see a tendency for gaps by parental income and employment status to widen slightly. Further analyses point to that all of these patterns were already in place a few months into pandemic, suggesting that learning gaps did not widen during the subsequent year in which most of the total lockdown period occurred. We also find some indication that boys and low-performing pupils suffered more from school closures than girls and highperforming pupils, but these differences are minor.
\end{abstract}

\section{Funding}

This research is supported by the Spar Nord Foundation. 


\section{Introduction}

The prolonged nature of the COVID-19 pandemic with several months of school closures has left policymakers and educators concerned about potential long-term consequences for children's learning. Although research shows evidence of a short-term learning loss (Hammerstein et al. 2021; Zierer 2021), little is known about the long-term consequences for learning and how they differ by family background. We examine whether school closures in Denmark has led to a learning loss among children about 14 months into the pandemic.

Distance learning has been criticized for being less effective than the face-to-face instruction that it has replaced, and the learning transition has in many places been hampered by lack of stable internet connectivity and availability of necessary digital tools (Domina et al. 2021; Grätz and Lipps 2021; Grewenig et al. 2021). A further concern has been that prolonged periods of social isolation may have worsened student engagement in school (Loades et al. 2020). Indeed, early studies on the effects of school closures in spring 2020 document a substantial learning loss. In a study on the Netherlands, Engzell et al. (2021) draw on longitudinal test score data on 350,000 pupils aged 8 to 11 and find an average learning loss of 3 percentile points, corresponding to eight weeks of lost learning, the same number of weeks that schools were closed. This result implies that "students made little or no progress while learning from home.” (Engzell et al. 2021, p. 1). Other studies relying on longitudinal data on standardized tests find learning losses of similar magnitude in China (Clark et al. 2021), Italy (Contini et al. 2021), and the United States (Kuhfeld et al. 2020; Pier et al. 2021). Studies relying on cross-sectional comparisons generally find similar results (Blainey et al. 2020; Kogan and Lavertu 2021; Maldonado and De Witte 2021; Rose et al. 2021; Schult et al. 2021), although some find little or mixed evidence of a learning loss (Gore et al. 2021; Depping et al. 2021; Fälth et al. 2021). However, cross-sectional data do not allow for proper analysis of biases from cohort effects or non-participation, both of which may have been substantial during the pandemic (Werner and Woessmann 2021).

Studies with access to individual level data on family background generally find a social gradient in the learning loss (Engzell 2021; Pier et al. 2021), while Contini et al. (2021) only find a social gradient for high-performing students. For instance, Engzell et al. (2021) find the learning loss to be 50 percent larger among children whose parents do not have upper secondary schooling compared to children with at least one parent who does. These results echo what we know from the well-established social science literature on the "summer learning loss": disadvantaged children are those who suffer most from the learning break during the summer months when there is no formal schooling (Cooper et al. 1996; Downey et 
al. 2004; Alexander et al. 2007; von Hippel et al. 2018). As the structured learning environment of schools is replaced by home schooling, parents' resources are expected to play a very significant role for how children are able to keep up. Perhaps most importantly for the COVID-19 situation, advantaged parents are likely to have the economic and cultural resources to not only provide stimulating and structured learning environments but also to decode and translate instructions sent from teachers (Goudeau et al. 2020; Lareau 2000; Lareau and Calarco 2012).

Beyond these early findings, we know very little about the lasting effects of school closures. Yet, such knowledge is important, as there is no reason to expect that the initial learning loss can be extrapolated linearly to the substantially longer closure experiences that have followed in most countries (Werner and Woessmann 2021). In contrast, as schools and teachers have had time to develop active online teaching methods and students have had opportunity to adapt to them, weekly losses are likely to have been reduced. Preliminary findings from Belgium and the Netherlands indicate that the learning loss may indeed have halted during subsequent school closures (Gambi and De Witte 2021; Haelermans et al. 2021). Moreover, a number of studies suggest that students' performance in online-learning environments has generally increased during the pandemic (Meeter 2021; Spitzer and Musslick 2021; Tomasik et al. 2021; van der Velde 2021).

Danish schools were closed down twice in response to the COVID-19 pandemic. The first school closure started March 16, 2020, lasting for eight school weeks, whereas the second closure started December 21, 2020 and lasted for 14 school weeks. Denmark thus provides an interesting context for studying the long-term effects of school closures by being a country with relatively long-lasting closures, while having otherwise good preconditions for handling the educational disruption. The transition to distance learning was made relatively smooth by the reliable digital infrastructure with Denmark being one of the absolute topscorers in digital skills, broadband connectivity, and digital public services in Europe (European Commission 2020). Schools were better prepared for the second and longer school closure (Qvortrup et al. 2020) and received financial help from a political settlement, which allocated 35 million Euros towards extra teaching and student well-being efforts in the first half of 2021. The Danish response thus presents a potential best-case scenario for limiting the negative impact of school closures on students' learning.

Our study evaluates the effects of school closures prompted by the COVID-19 pandemic on children's academic performance more than one year into the pandemic. For this purpose, we use nationwide standardized reading test data on Danish public school pupils 
with very little attrition and very detailed and highly reliable information on family background. Controlling for cohort differences in family background and prior performance, we compare test scores from mid-2021 to what would be expected from test score trajectories in the years prior to the pandemic (i.e., 2017-2019). To examine family background gaps in the learning loss, we use a difference-in-differences approach to compare the average development in reading performance for individual pupils between school years (e.g., between grades 4 and 6) before and after the pandemic and for different social groups defined by gender, ethnicity, family type, prior performance, and parental education, income, and/or employment. These approaches and the underlying research hypotheses were pre-registered (see Supplementary material A).

The empirical results show no evidence of any major learning slide in Denmark. Only among the oldest pupils in grade 8 do we find a decrease in reading performance of about 3 percentile points. Among the youngest pupils, particularly those in grades 2 and 4, there is even evidence of a learning gain of about 5 percentile points. However, these pupils are also those least affected by school closures with only about eight weeks of distance learning compared to 22 weeks among pupils in grades 6 and 8. Importantly, we find only little evidence of widening learning gaps by socioeconomic origin. Still, in grade 8 we see a tendency for gaps by parental income and employment to widen slightly. Nonetheless, these patterns were already in place after the initial lockdown in spring 2020, suggesting that learning gaps did not widen during subsequent and longer school closures. Finally, we find some indication that boys and low-performing pupils suffered more from school closures than girls and high-performing pupils, but these differences are relatively small.

\section{Results}

\section{Overall learning development}

In Figure 1, we depict the development in reading test scores by standardizing test scores to percentile ranks within each grade level over the entire period 2015-2021 (excl. 2020). To assess the magnitude of the change in reading test scores, we compare test scores in 2021 to what would be expected from test score trajectories three years prior to the pandemic, also adding controls for cohort differences in family background and school fixed effects. Figure 2 shows the estimated learning losses by grade level and different model specifications. The estimates denoted "all controls" in Figure 2 show a learning gain of 4.8 percentile points in 
grade 2, 5.1 percentile points in grade 4, and 3.0 percentile points in grade 6 . In grade 8 , we find a learning loss of -2.8 percentile points.

In a supplementary analysis of math test scores, we find a similar pattern (see Supplementary material C2): a learning gain of 1.2 percentile points in grade 3 , no development in performance in grade 6 , and a learning loss of -2.8 percentile points in grade 8. Although the impact of school closures thus appears to be smaller for math test scores than reading test scores, the pattern of learning loss in grade 8 and learning gains in lower grades is similar.

In an additional supplementary analysis, we consider reading test scores in 2020 (see Supplementary material C3). In this year, the national tests were only conducted on a ninepercent random sample of schools. For reasons of comparability, in this analysis we restrict our sample to these randomly sampled schools, also back in time. Reading tests were conducted mainly in May and June 2020 when schools re-opened after being closed on March 16. We find no significant development in reading test scores in grades 2, 4, or 6, suggesting that the learning gain experienced by younger pupils materialized in the period after the initial school closure in spring 2020. However, we find a learning loss of -3.5 percentile points in grade 8 . Although these estimates are associated with a degree of uncertainty due to the smaller sample size and later month test taking, they suggest that the learning loss among pupils in grade 8 was already formed after the initial school closure and did not increase substantially in the subsequent period with much longer school closures. 
Figure 1. Development in reading test scores by grade level.

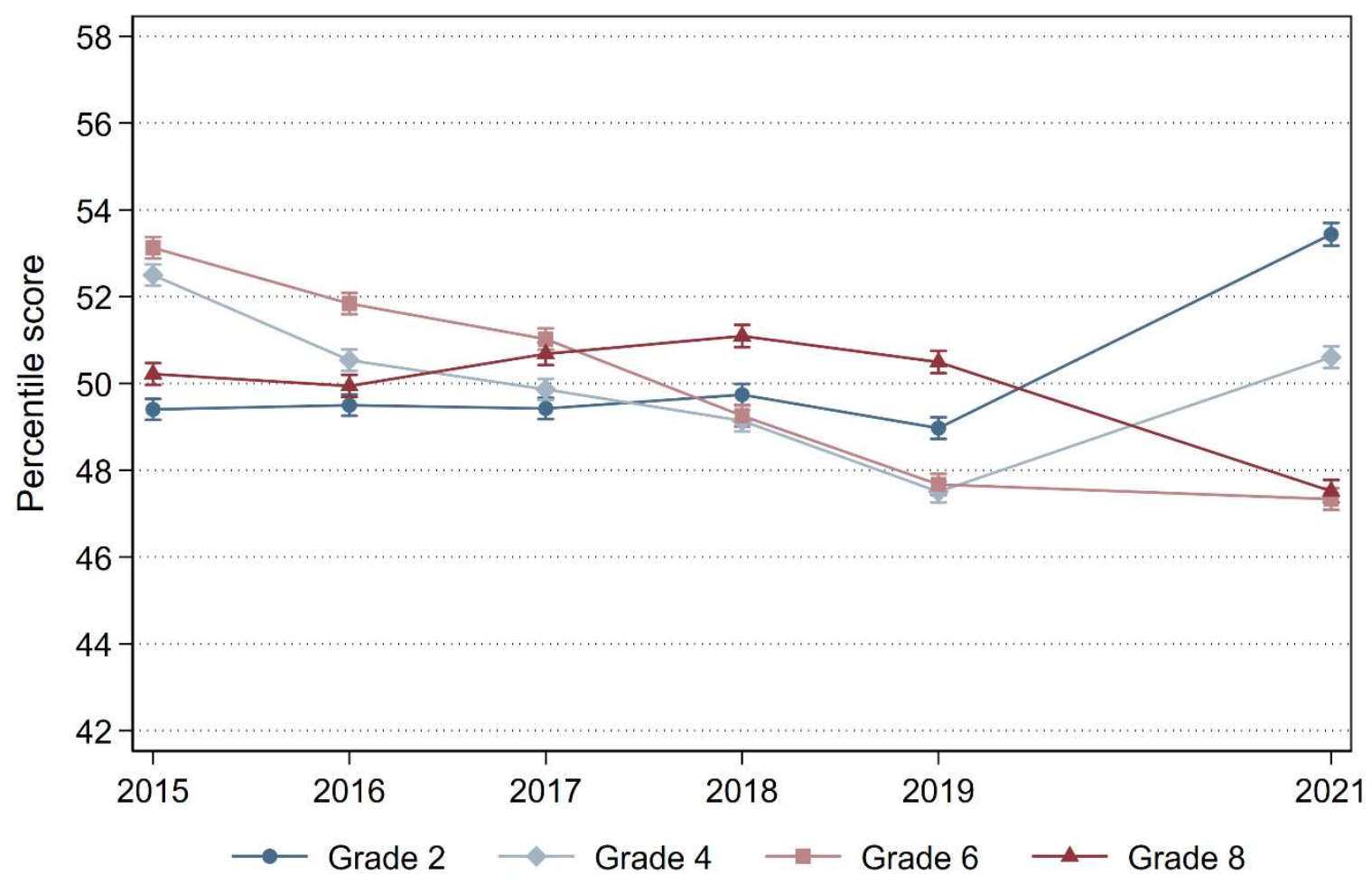

Figure 2. Estimates of the 2021 learning development in reading by grade level.
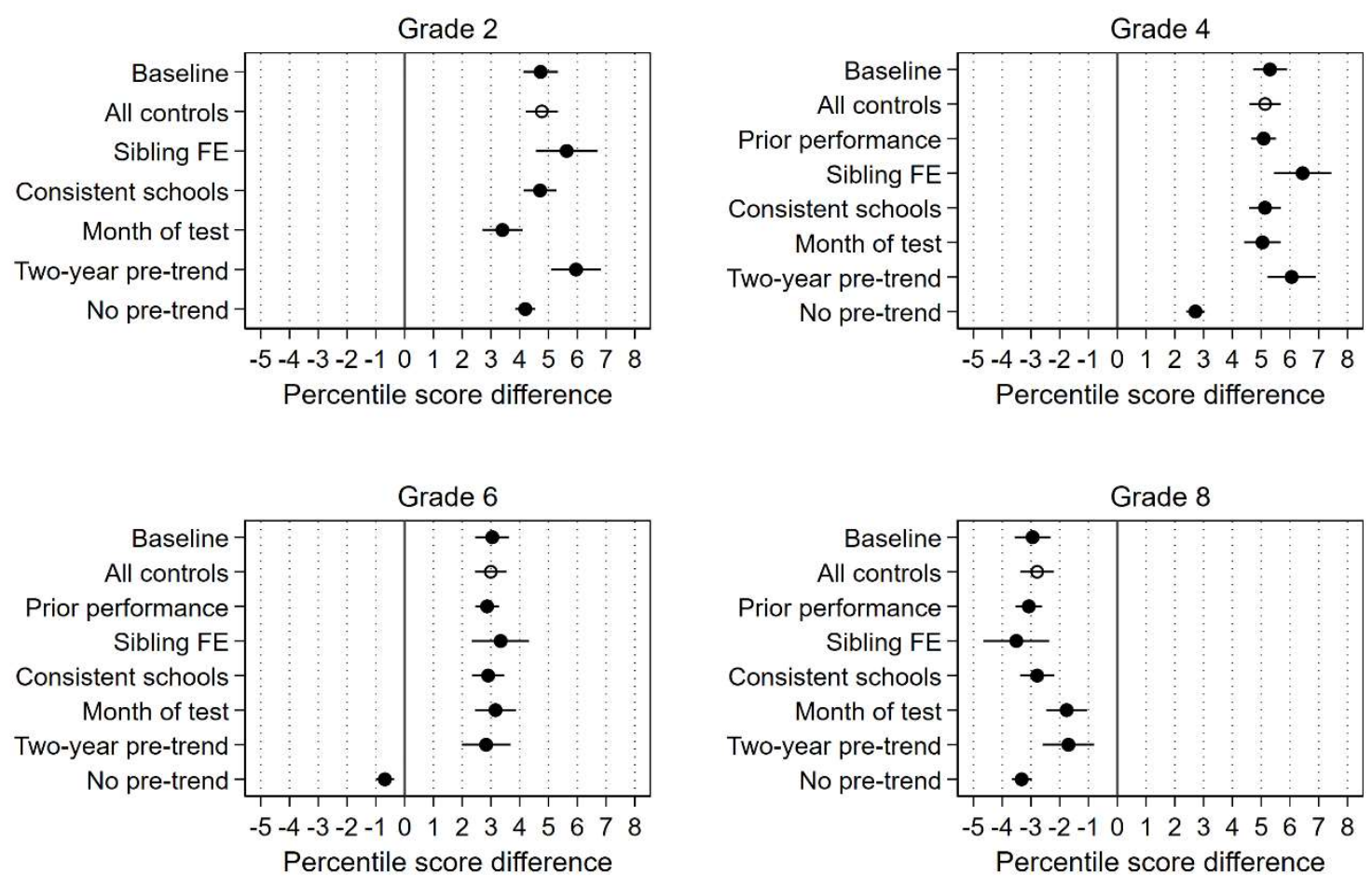


\section{Learning gaps by family background}

To examine family background gaps in learning progress, we compare the average development in reading performance for individual pupils between school years before and after the pandemic and for different sociodemographic groups using the difference-indifferences approach (see equation (3) in the methods section).

Table 1 reports the results. Although we find no differences in learning progress with regard to ethnic origin, family type, or parental education, we observe some differences with regard to parental income, parental employment, gender, and prior performance. In grade 8 , we find that the learning loss is greater among pupils with parents who are unemployed or belong to the bottom income quartile. The difference in the learning loss between having parents in the top and bottom income quartile is about 2 percentile points, which is a moderately sized difference given that these groups were already separated by more than 20 percentile points in reading performance at the baseline in 2019 (see Supplementary material, Table B6). In grade 4, the picture is almost the opposite, as pupils whose parents belong to the top income quartile tend to lose ground, particularly to pupils whose parents belong to the 2nd and 3rd income quartile, suggesting that learning gaps by socioeconomic background narrowed slightly during the pandemic. In an additional analysis, we find a very similar pattern emerging already in mid-2020, suggesting that the pattern is a result of the first school closure in 2020 and did not develop considerably afterwards (see Supplementary material C3).

In grades 4 and 6 , we also find that boys lose about 2 percentile points in reading performance relative to girls, suggesting that the gender gap increased in 2021, as boys also trailed behind girls in reading performance at the baseline in 2019. Finally, for all grade levels, we find that pupils in the bottom quartile of prior performance lost 1-2 percentile points in reading performance relative to top-readers, suggesting a slightly increasing polarization of reading performance. 
Table 1. Differences in the 2021 learning development in reading by sociodemographic groups.

\begin{tabular}{|c|c|c|c|c|}
\hline & $\begin{array}{l}\text { Grade } \\
(2-) 4\end{array}$ & $\begin{array}{c}\text { Grade } \\
(4-) 6\end{array}$ & $\begin{array}{c}\text { Grade } \\
(6-) 8\end{array}$ & Pooled \\
\hline \multicolumn{5}{|l|}{ Gender (ref: Girl) } \\
\hline Boy & $\begin{array}{c}-1.64 * * * \\
(0.50)\end{array}$ & $\begin{array}{c}-1.70 * * * \\
(0.46)\end{array}$ & $\begin{array}{l}-0.11 \\
(0.52)\end{array}$ & $\begin{array}{c}-1.17 * * * \\
(0.28)\end{array}$ \\
\hline \multicolumn{5}{|l|}{ Ethnicity (ref: Danish origin) } \\
\hline Children of immigrants & $\begin{array}{c}0.47 \\
(0.91)\end{array}$ & $\begin{array}{l}-0.82 \\
(0.91)\end{array}$ & $\begin{array}{l}-1.11 \\
(1.06)\end{array}$ & $\begin{array}{l}-0.63 \\
(0.56)\end{array}$ \\
\hline Immigrants & $\begin{array}{c}0.70 \\
(1.43)\end{array}$ & $\begin{array}{c}0.87 \\
(1.40)\end{array}$ & $\begin{array}{c}1.53 \\
(1.75)\end{array}$ & $\begin{array}{c}1.13 \\
(0.88)\end{array}$ \\
\hline \multicolumn{5}{|l|}{ Parental education (ref: College) } \\
\hline Less than college & $\begin{array}{c}0.81 \\
(0.50)\end{array}$ & $\begin{array}{l}-0.15 \\
(0.46)\end{array}$ & $\begin{array}{l}-1.00 \\
(0.52)\end{array}$ & $\begin{array}{l}-0.08 \\
(0.28)\end{array}$ \\
\hline \multicolumn{5}{|l|}{ Parental income (ref: Top quartile) } \\
\hline 3rd quartile & $\begin{array}{l}1.58^{*} \\
(0.67)\end{array}$ & $\begin{array}{l}-0.35 \\
(0.61)\end{array}$ & $\begin{array}{l}-1.02 \\
(0.69)\end{array}$ & $\begin{array}{c}0.10 \\
(0.38)\end{array}$ \\
\hline 2nd quartile & $\begin{array}{c}2.61 * * * \\
(0.69)\end{array}$ & $\begin{array}{l}-0.19 \\
(0.63)\end{array}$ & $\begin{array}{l}-1.32 \\
(0.70)\end{array}$ & $\begin{array}{c}0.41 \\
(0.39)\end{array}$ \\
\hline Bottom quartile & $\begin{array}{c}1.16 \\
(0.70)\end{array}$ & $\begin{array}{l}-0.63 \\
(0.65)\end{array}$ & $\begin{array}{c}-2.10^{* *} \\
(0.75)\end{array}$ & $\begin{array}{l}-0.47 \\
(0.40)\end{array}$ \\
\hline \multicolumn{5}{|c|}{ Parental employment (ref: Both parents employed) } \\
\hline At least one parent unemployed & $\begin{array}{c}0.59 \\
(0.68)\end{array}$ & $\begin{array}{l}-0.23 \\
(0.62)\end{array}$ & $\begin{array}{c}-2.28 * * \\
(0.71)\end{array}$ & $\begin{array}{l}-0.62 \\
(0.39)\end{array}$ \\
\hline \multicolumn{5}{|l|}{ Family type (ref: Intact family) } \\
\hline Non-intact family & $\begin{array}{l}-0.07 \\
(0.55)\end{array}$ & $\begin{array}{l}-0.64 \\
(0.49)\end{array}$ & $\begin{array}{l}-0.22 \\
(0.55)\end{array}$ & $\begin{array}{l}-0.30 \\
(0.30)\end{array}$ \\
\hline \multicolumn{5}{|l|}{ Prior performance (ref: Top quartile) } \\
\hline 3rd quartile & $\begin{array}{l}-0.72 \\
(0.63)\end{array}$ & $\begin{array}{l}-0.65 \\
(0.58)\end{array}$ & $\begin{array}{c}0.47 \\
(0.65)\end{array}$ & $\begin{array}{l}-0.32 \\
(0.36)\end{array}$ \\
\hline 2nd quartile & $\begin{array}{l}-0.62 \\
(0.64)\end{array}$ & $\begin{array}{c}0.33 \\
(0.59)\end{array}$ & $\begin{array}{c}0.20 \\
(0.67)\end{array}$ & $\begin{array}{c}-0.04 \\
(0.37)\end{array}$ \\
\hline Bottom quartile & $\begin{array}{l}-1.33 * \\
(0.61)\end{array}$ & $\begin{array}{l}-1.30^{*} \\
(0.56)\end{array}$ & $\begin{array}{l}-1.64 * \\
(0.64)\end{array}$ & $\begin{array}{c}-1.41 * * * \\
(0.35)\end{array}$ \\
\hline
\end{tabular}

Note: Standard errors in parenthesis. ${ }^{*} \mathrm{p}<0.05,{ }^{* *} \mathrm{p}<0.01,{ }^{* * *} \mathrm{p}<0.001$. 


\section{Robustness tests}

We find that our estimates of the learning development during the COVID-19 pandemic are robust to a range of sensitivity tests. First, results are virtually unaffected by controlling for a two-year lagged measure of reading performance, suggesting that results are not affected by cohort differences in performance (see Figure 2). Second, we use that our data include siblings that have taken the national tests at the same grade levels but in different years. Results are robust to controlling for sibling fixed effects, further ensuring that results are not confounded by cohort differences in family background composition. Third, results are robust to excluding schools who did not participate in the national tests in each of the years 2017, 2018, 2019, 2021, which applies to only 5 percent of schools in 2021. Fourth, we control for month of test to take into consideration that the test in 2021 was postponed by about four school weeks on average. Results are robust to this control. Moreover, even if we factor in a four week difference, amounting to a potential 1.5 percentage points learning gain (Azevedo et al. 2021; Engzell et al. 2021), it would not affect the overall pattern of results we report. Younger children would still experience a learning gain, although smaller, and older children would experience a slightly larger learning loss.

Fifth, although results are generally robust to changing the three-year pre-trend to a two-year pre-trend, completely leaving out a pre-trend changes the results markedly for grades 4 and 6 , in both instances reducing the estimate of the learning gain. This result is due to the slightly downwards trend in reading test scores for these two grade levels between 2015 and 2019 as can be seen from Figure 1. Thus, not taking pre-trends into account will lead to underestimating the learning gain for these grade levels (Engzell et al. 2021). Sixth, we conduct a placebo analysis, meaning that we exclude the actual treatment year (2021) and, by turn, assign treatment to each of the pre-treatment years (2015-2019). Supplementary material C4 shows that placebo effects are very small with all 52 placebo estimates being lower than 1.5 percentile points in magnitude and most being lower than 0.5 percentile point, documenting that the development in reading test scores were relatively stable prior to the pandemic. Seventh, we ensure that within-individual correlations in reading test scores are similar in 2021 compared to previous years to validate that test scores are indeed comparable across time. Supplementary material C5 shows that these correlations hover around 0.70 in all grade levels and years, indicating that even though the adaptive tests are not exactly the same across time, they consistently measure the same underlying construct each year. 


\section{Discussion}

In this study, we document the effects of school closures prompted by the COVID-19 pandemic on children's reading performance in mid-2021 - more than one year into the pandemic in Denmark - and find little evidence of any major learning slide. Still, among older pupils in grade 8 we find a decrease in reading performance of about 3 percentile points, corresponding to 7 weeks of lost learning using the World Bank benchmark for yearly learning progress (Azevedo et al. 2021; Engzell et al. 2021). This provides some evidence that long school closures may have a detrimental effect on children's learning, as pupils in grade 8 were exposed to 22 school weeks of distance learning compared to only eight weeks among pupils in grades 2 and 4 among whom we do not observe any learning loss. However, we also do not observe a learning loss among pupils in grade 6 , who were similarly exposed to distance learning as were pupils in grade 8, if anything, pupils in grade 6 experienced a small learning gain. Moreover, we find a learning loss of similar magnitude among pupils in grade 8 already two months into the pandemic in mid-2020, suggesting that the learning loss formed as a result of the initial school closure in spring 2020 and did not grow during the substantially longer school closure in the first half of 2021. It thus seems possible that schools, teachers, and pupils were better prepared for and have adjusted to the online learning format in the second round of school closures (Qvortrup et al. 2021).

Among the youngest pupils in grades 2 and 4, we find evidence of a learning gain of about 5 percentile points in 2021. Three aspects of the Danish school closures may help shed some light on this somewhat surprising finding. First, the youngest pupils were exposed to much shorter periods of distance learning of only three school weeks during the first school closure and five weeks during the second. Second, to minimize the spread of the virus and also to increase student well-being, the youngest children were taught by few, familiar teachers when they returned to school (The Danish Evaluation Institute 2021). This often resulted in most or all subjects being covered by the Danish teacher, who may have favored reading lessons over other subjects. Third, during the time when older students were still being taught from home, most teachers reported to have made use of the additional space to divide classrooms into smaller groups, bringing extra teacher resources or substitute teachers into play (The Danish Evaluation Institute 2021).

Although we find little evidence of widening learning gaps by socioeconomic origin during the pandemic for pupils in grades 2,4 , and 6, we see a tendency for gaps by parental income and employment status to widen somewhat for pupils in grade 8 . These patterns were already visible after the school closure in spring 2020, suggesting that learning gaps did not 
grow during subsequent school closures. This result is surprising given that so much of the teaching burden were shifted to parents during school closures as parents in the absence of teachers were expected to help their children plan and structure their school days. However, although evidence points to well-educated parents being more fit to fill out this supportive role (Andrew et al. 2020; Bol 2020; Jæger and Blaabæk 2020), a recent study on Denmark did not find any long-term influence on inequality in children's reading activity during the pandemic (Reimer et al. 2021). Inequality in home advantage may to some extent have been counteracted by emergency care arrangements in schools for children with special social or educational needs. About five percent of Danish schoolchildren made use of this scheme (Christensen 2021). After the first school closure, a political settlement also set aside 10 million Euros so that municipalities could apply for funding to organize summer schools, study cafés, or other initiatives targeting socially and academically disadvantaged students.

We also find some evidence that the reading performance of low-performing pupils suffered more from school closures than that of high-performing pupils. This finding may be explained by the fact that pupils who already did well in school were the ones who benefitted the most from setting their own pace when learning from home (The Danish Evaluation Institute 2021). Nonetheless, these relative group differences are comparatively smaller than the overall gains in reading performance that we observe among pupils in the lower grades, suggesting that the polarizing effects of the pandemic are inconsequential. Similarly, while boys appear to be have been hampered more by the pandemic in their learning progression than girls, thus slightly increasing the gender gap in reading skills, the gender polarization is inconsequential in light of the overall gains achieved by pupils in the lower grades.

In conclusion, our study shows that school closures following the COVID-19 pandemic have not resulted in any major, long-run learning slide in Denmark. This conclusion aligns with recent findings from Belgium and the Netherlands in which an initial loss has not widened substantially over time (Gambi and De Witte 2021; Haelermans et al. 2021). Moreover, we do not see any substantial differences among children from different family backgrounds, pointing to that school closures have been largely socially neutral. While we cannot pinpoint the factors responsible for reducing the severity, the evidence points to that national responses seen in Denmark likely have mitigated a potentially large and socially skewed learning loss. 


\section{Methods}

\section{Study setting}

Danish schools were closed down twice in response to the COVID-19 pandemic. The first school closure started March 16, 2020 and lasted for eight school weeks. The second school closure was initiated in response to rising infection rates on December 21, 2020 and was significantly longer than the first shutdown, lasting for 14 school weeks. Only the oldest pupils in grades 6 to 8 were exposed to the full 22 school weeks of distance learning, which amounts to half of the total number of school weeks between March 16, 2020 and May 6, 2021. Younger pupils in grades 0 to 4 were allowed back in school early on both occasions and were exposed to distance learning for a total of eight school weeks. In addition to these nationwide school closures, there have been numerous local school closures in areas with high infection rates, meaning that 22 (8) weeks of distance learning is the minimum period of exposure.

A teacher survey from the first school closure in spring 2020 shows that the vast majority of older pupils' lessons were successfully replaced by live classroom teaching using video conferencing software such as Skype or Microsoft Teams (The Danish Evaluation Institute 2021). Among the younger pupils, however, particularly those in grades 1 to 3, this type of online classroom teaching was rare, whereas it was used by about half of teachers in grades 4 to 6 . Younger pupils instead regularly received written instructions from teachers about which distributed assignments they should work on at home, if possible with help from parents. Older pupils in grades 5 to 9 were surveyed during both school closures and experienced that distance teaching had become more structured and varied and teachers more accessible in the second school closure (Qvortrup et al. 2021). However, pupils also experienced school work during the lockdown as lonely, repetitive, and less instructive than normal classroom teaching in which pupils usually are asked to work together in pairs or groups (The Danish Evaluation Institute 2021). Still, about one third of pupils reported to have been more motivated to study during lockdown with fewer disturbances and more opportunity to concentrate as primary explanations.

\section{Data}

The analysis was conducted using Danish national test score data made available by The National Agency for IT and Learning (Styrelsen for IT og Læring) under the Ministry of Children and Education. The dataset contains results from standardized tests in reading conducted yearly between 2015 and 2021 among all Danish public school pupils in grades 2, 
4, 6, and 8 (i.e., ages 8, 10, 12, and 14). While we exclude test score data from 2020 in the main analysis, we use it in an additional analysis to examine the impact on learning of the first school closure in spring 2020. ${ }^{1}$ We link the national test score data to the administrative registers at Statistics Denmark via personal identification numbers. From these registers, we obtain complete and highly reliable information on gender, ethnic origin, family type, number of siblings, and parental education, employment, and income. Given that we work with administrative data, our sample covers the vast majority of schoolchildren in a given grade in a given year, meaning that we have available total population data $(\mathrm{N} \approx 200.000$ per year).

\section{Test scores}

Our main dependent variable is the Danish national test scores in reading. The test is conducted each year among all Danish public school pupils in grades 2, 4, 6, and 8 . It is carried out at school using an online, self-scoring, and adaptive program that taps into three cognitive domains of language comprehension, decoding, and reading comprehension. Reading test questions involve, for example, word-to-picture matching, word splitting, or reading a text and answering content-related questions. The adaptive nature of the test means that the difficulty level of questions continuously adapts to the test subject's demonstrated ability level with the online test system drawing questions from the same large national item bank ensuring that test scores are comparable across schools and test years within school grades (Beuchert and Nandrup 2018). Test scores are, however, not comparable across school grades, meaning that we cannot measure an individual's reading progression between, for example, grades 4 to 6 . Still, we can measure progression in an individual's relative reading rank and thus also any gaps in the relative progression of social groups defined by gender, ethnicity, or parents' socioeconomic resources.

In all previous years (2015-2019), the majority of pupils has been tested in the month of April. However, in 2021 the majority took the test in May, when schools began re-opening (see Supplementary material, Table B4). Thus the test taking is separated by about four school weeks, amounting to a potential 1.5 percentage points learning gain according to the World Bank benchmark for yearly learning progress (Azevedo et al. 2021; Engzell et al. 2021), which could affect the estimated learning loss. We deal with this data feature in two ways. First, we present estimates for which we control for month of test. Second, we bound

\footnotetext{
${ }^{1} 2020$ stands out as being the only test year where not the full student population were tested. Instead, a ninepercent random percent sample of schools was issued.
} 
our estimates in light of this potential bias. Both auxiliary analyses show that timing of the test cannot alter any of the key conclusions we present.

The Danish national test data also include a yearly standardized math test in grades 3, 6, and 8. However, data is only available for years 2016-2021 for grade 3 and years 20182021 for grades 6 and 8 . Because of the limited measurement period, we only use the math test data to check the robustness of our main results based on the reading test data.

\section{Independent variables}

Independent variables include parental education, employment, and income as well as gender, ethnic origin, family type, and number of siblings (see Supplementary material, Table B5). Our measure of parental education distinguishes between at least one parent holding a college degree $(\sim 48 \%)$ and both parents with less than a college degree ( $\sim 52 \%)$. Our measure of parental employment distinguishes between both parents being employed ( 82\%) and at least one parent being unemployed ( $18 \%)$, defined as receiving unemployment benefits, cash assistance, or disability pension. Parental income is measured as parents' total disposable income from wage employment, self-employment, and public transfers after tax, coded into quartiles. Our measure of ethnic origin distinguishes between children of Danish origin ( $\sim 89 \%)$, children of immigrants ( $\sim 8 \%)$, and immigrants ( 4\%). Our measure of family type distinguishes between intact (two-parent) families $(\sim 68 \%)$ and families in which parents live separately $(\sim 32 \%)$.

\section{Analytical approach}

We analyze the impact of the COVID-19 pandemic on children's learning using two statistical approaches. These approaches and the underlying research hypotheses were preregistered (see Supplementary material A). In the first approach, we estimate the overall learning loss using a linear regression model with the following specification:

$\operatorname{read}_{i s}=\alpha+\delta T_{i s}+$ eyear $_{i s}+\varepsilon_{i s}$

where $\mathrm{read}_{\text {is }}$ is the reading test score for individual $i$ in school $s, T_{i s}$ is an indicator for the treatment year 2021 and year ${ }_{i s}$ is a linear trend of the remaining years of testing. In this specification, reading test scores are standardized to percentile ranks within each grade level over the period 2017-2021 (excl. 2020). The parameter of interest, $\delta$, thus captures the degree to which the 2021 test scores deviate (in terms of percentile points) from what would 
be expected from the progression in test scores in the years leading up to the pandemic (i.e., 2017-2019) (Engzell et al. 2021). A causal interpretation of the estimate is based on the assumption that in the absence of the pandemic the development of test scores would have followed the same trend as in previous years.

To ensure that results are not confounded by changes in student composition across years, we also include weights for test absenteeism (which only concerns about 4 percent of the tests in 2021; see Supplementary material B, Tables B2 and B3), control variables for a range of family background characteristics, and school fixed effects:

$\operatorname{read}_{i s}=\alpha+\delta T_{i s}+\theta y e a r_{i s}+\beta X_{i s}+\gamma_{i s}+\varepsilon_{i s}$

where $X_{i s}$ is a vector that includes gender, ethnic origin, family type, number of siblings, and parental education, employment, and income, and $\gamma_{i s}$ are school fixed effects. We estimate Equations (1) and (2) separately for each grade level (i.e., grades 2, 4, 6, and 8).

In the second approach, we examine whether the learning loss varies by family background characteristics using a difference-in-differences approach (Engzell et al. 2021). We use the panel structure of the data to analyze the progression of individual students: $\Delta$ read $_{i s}=$ read $_{i s}^{\text {grade } g}-$ read $_{i s}^{\text {grade }}$-2 , where $g$ is grades 4,6 , or 8 . In this specification reading test scores are standardized to percentile ranks within each grade level and year. The average progression of students are thus by definition zero. Nonetheless, the progression of different social groups in the data may differ and we can thus gauge whether the gap in the relative positions between social groups has increased, remained stable, or reduced as a result of the pandemic. Thus, we estimate a number of difference-in-differences models that take the following form:

$\Delta \operatorname{read}_{i s}=\alpha+\delta T_{i s}+\theta y e a r_{i s}+\beta Z_{i s}+\pi T_{i s} * Z_{i s}+$ yyear $_{i s} * Z_{i s}+\gamma_{i s}+\varepsilon_{i s}$

where $Z_{i s}$ is one of the covariates gender, ethnic origin, family type, prior performance, parental education, parental employment, or parental income, which are entered into the model one at a time. $\pi$ is the parameter of interest: it captures the difference in relative learning progression by each of the groups captured in $Z_{i s}$. Importantly, we also include interaction terms between $y e a r_{i s}$ and $Z_{i s}$ to capture any potential differences in pre-trends by 
social groups defined by the covariates. ${ }^{2}$ One advantage of the difference-in-differences approach is that in ensures that results are not confounded by random fluctuations in student performance over time. ${ }^{3}$

\footnotetext{
${ }^{2}$ In a separate analysis, we ensure that pre-trends are sufficiently parallel between social groups, which is an important prerequisite for the causal interpretation of $\pi$ (see Supplementary material C6).

${ }^{3}$ Another advantage of this approach is that it is not biased by the month of test taking, given that we are only concerned with gaps in relative ranks or positions, not absolute learning gaps.
} 


\section{References}

Alexander, K. L., Entwisle, D. R., and Olson, L. S. (2007). Lasting consequences of the summer learning gap. American Sociological Review, 72(2), 167-180.

Andrew, A., Cattan, S., Costa Dias, M., Farquharson, C., Kraftman, L., Krutikova, S., Phimister, A., and Sevilla, A. (2020). Inequalities in Children's Experiences of Home Learning during the COVID-19 Lockdown in England. Fiscal Studies, 41(3), 653-683.

Azevedo, J. P., Hasan, A., Goldemberg, D., Geven, K., and Iqbal, S. A. (2021). Simulating the potential impacts of COVID-19 school closures on schooling and learning outcomes: A set of global estimates. The World Bank Research Observer, 36(1), 140 .

Beuchert, L.V. and Nandrup, A. B. (2018). The Danish National Tests at a Glance. Nationaløkonomisk Tidsskrift, 2018(2), 1-37.

Blainey, K., Hiorns, C., and Hannay, T. (2020). The impact of lockdown on children's education: A nationwide analysis. RS Assessment from Hodder Education. https://www.risingstars-uk.com/media/RisingStars/Assessment/Whitepapers/RS Assessment white paper 1.pdf.

Bol, T. (2020). Inequality in homeschooling during the Corona crisis in the Netherlands. First results from the LISS Panel. SocArXiv Working Paper. https://doi.org/10.31235/osf.io/hf32q.

Christensen, E. B. (2021). Kommunerne yder stor indsats over for udsatte skoleelever [The municipalities make great efforts towards disadvantaged pupils]. The National Association of Municipalities, online article.

https://www.kl.dk/forsidenyheder/2021/februar/kommunerne-yder-stor-indsats-overfor-udsatte-skoleelever.

Clark, A. E., Nong, H., Zhu, H., and Zhu, R. (2021). Compensating for academic loss: Online learning and student performance during the COVID-19 pandemic. China Economic Review, 68, 101629.

Contini, D., Di Tommaso, M. L., Muratori, C., Piazzalunga, D., and Schiavon, L. (2021). The COVID-19 Pandemic and School Closure: Learning Loss in Mathematics in Primary Education. IZA Discussion Paper 14785. Bonn: IZA Institute of Labor Economics.

Cooper, H., Nye, B., Charlton, K., Lindsay, J., and Greathouse, S. (1996). The effects of summer vacation on achievement test scores: A narrative and meta-analytic review. Review of Educational Research, 66(3), 227-268.

Depping, D., Lücken, M., Musekamp, F., and Thonke, F. (2021). Kompetenzstände Hamburger Schüler*innen vor und während der Corona-Pandemie. Pp. 51-79 in Fickermann, D. and Edelstein, B. (eds.) Schule während der Corona-Pandemie. Neue Ergebnisse und Überblick über ein dynamisches Forschungsfeld. Münster: Waxmann. 
Domina, T., Renzulli, L., Murray, B., Garza, A. N., and Perez, L. (2021). Remote or removed: Predicting successful engagement with online learning during COVID-19. Socius, 7, 2378023120988200.

Downey, D. B., Von Hippel, P. T., and Broh, B. A. (2004). Are schools the great equalizer? Cognitive inequality during the summer months and the school year. American Sociological Review, 69(5), 613-635.

Engzell, P., Frey, A., and Verhagen, M. D. (2021). Learning loss due to school closures during the COVID-19 pandemic. Proceedings of the National Academy of Sciences, $118(17)$, e2022376118.

European Commission (2020). Digital Economy and Society Index (DESI) 2020. Thematic chapters. https://digital-strategy.ec.europa.eu/en/policies/desi.

Fälth, L., Hallin, E. A., and Nordström, T. (2021). Corona-pandemins påverkan på lågstadieelevers läsinlärning. LegiLexi. https://legilexi.org/media/1805/legilexi_coronarapport_2021.pdf.

Gambi, L. and De Witte, K. (2021). The resiliency of school outcomes after the COVID-19 pandemic. Standardised test scores and inequality one year after long term school closures. KU Leuven Discussion Paper Series DPS21.12.

https://feb.kuleuven.be/research/economics/ces/documents/DPS/DPS2021/dps\%202 112.pdf.

Gore, J., Fray, L., Miller, A., Harris, J., and Taggart, W. (2021). The impact of COVID-19 on student learning in New South Wales primary schools: An empirical study. The Australian Educational Researcher, 48, 605-637.

Goudeau, S., Sanrey, C., Stanczak, A., Manstead, A., and Darnon, C. (2021). Why lockdown and distance learning during the COVID-19 pandemic are likely to increase the social class achievement gap. Nature Human Behaviour, 5, 1273-1281.

Grätz, M., \& Lipps, O. (2021). Large loss in studying time during the closure of schools in Switzerland in 2020. Research in Social Stratification and Mobility, 71, 100554.

Grewenig, E., Lergetporer, P., Werner, K., Woessmann, L., and Zierow, L. (2021). COVID19 and educational inequality: How school closures affect low-and high-achieving students. European Economic Review, 140, 103920.

Haelermans, C., van der Velden, R., Aarts, B., Bijlsma, I., Jacobs, M., Smeets, C., van Vugt, L., \& van Wetten, S. (2021). Balans na anderhalf jaar: Vertraging leergroei het grootst voor rekenen-wiskunde. NCO Factsheet No. 8. https://www.nationaalcohortonderzoek.nl/sites/nco/files/mediafiles/factsheet08 nco algemeen 0.pdf.

Hammerstein, S., König, C., Dreisörner, T., and Frey, A. (2021). Effects of COVID-19Related School Closures on Student Achievement-A Systematic Review. PsyArXiv Working Paper. https://doi.org/10.31234/osf.io/menvk.

Jæger, M. M. and Blaabæk, E. H. (2020). Inequality in learning opportunities during Covid19: Evidence from library takeout. Research in Social Stratification and Mobility, 68, 100524. 
Kogan, V. and Lavertu, S. (2021). The COVID-19 pandemic and student achievement on Ohio's third-grade English language arts assessment. Online report:

http://glenn.osu.edu/educational-governance/reports/reportsattributes/ODE ThirdGradeELA_KL 1-27-2021.pdf.

Kuhfeld, M., Ruzek, E., Johnson, A., Tarasawa, B., and Lewis, K. (2020). Technical appendix for: Learning during COVID-19: Initial findings on students' reading and math achievement and growth. NWEA.

https://www.nwea.org/research/publication/technical-appendix-for-learning-duringcovid-19-initial-findings-on-students-reading-and-math-achievement-and-growth.

Lareau, A. (2000). Home advantage: Social class and parental intervention in elementary education. Rowman \& Littlefield Publishers.

Lareau, A. and Calarco, J. M. (2012). Class, Cultural Capital, and Institutions: The Case of Families and Schools. Pp. 61-86 in Fiske, S. and Markus, H. R. (eds.) Facing Social Class: How Societal Rank Influences Interaction. New York: Russel Sage Foundation.

Loades, M.E., Chatburn, E., Higson-Sweeney, N., Reynolds, S., Shafran, R., Brigden, A., Linney, C., McManus, M.N., Borwick, C., and Crawley, E. (2020). Rapid systematic review: The impact of social isolation and loneliness on the mental health of children and adolescents in the context of COVID-19. Journal of the American Academy of Child \& Adolescent Psychiatry, 59(11), 1218-1239.

Maldonado, J. E. and De Witte, K. (2021). The effect of school closures on standardised student test outcomes. British Educational Research Journal. https://doi.org/10.1002/berj.3754.

Meeter, M. (2021). Primary school mathematics during Covid-19: No evidence of learning gaps in adaptive practicing results. PsyArXiv Working Paper. https://doi.org/10.31234/osf.io/8un6x.

Pier, L., Christian, M., Tymeson, H., and Meyer, R. H. (2021). COVID-19 impacts on student learning: Evidence from interim assessments in California. Policy Analysis for California Education. https://edpolicyinca.org/publications/covid-19-impactsstudent-learning.

Qvortrup, L., Christensen, J. H., and Wistoft, K. (2021). Skolenedlukninger I Århus Kommune under corona-pandemien i et elev- og forældreperspektiv: En sammenligning mellem foråret 2020 og vinteren 2021 [School closures in Aarhus Municipality during the corona pandemic in a pupil and parent perspective: A comparison of spring 2020 and winter 2021]. DPU, Aarhus Universitet. https://ncs.au.dk/fileadmin/NCS/Projekter/Noedundervisning_under_coronakrisen/Corona-rapport_skoler_AArhus_Kommune_2020_2021.pdf

Reimer, D., Smith, E., Andersen, I. G., and Sortkær, B. (2021). What happens when schools shut down? Investigating inequality in students' reading behavior during Covid-19 in Denmark. Research in Social Stratification and Mobility, 71, 100568. 
Rose, S., Twist, L., Lord, P., Rutt, S., Badr, K., Hope, C., and Styles, B. (2021). Impact of school closures and subsequent support strategies on attainment and socio-emotional wellbeing in Key Stage 1: Interim Paper 1. National Foundation for Educational Research, London. https://www.nfer.ac.uk/impact-of-school-closures-andsubsequent-support-strategies-on-attainment-and-socio-emotional-wellbeing.

Schult, J., Mahler, N., Fauth, B., and Lindner, M. A. (2021). Did students learn less during the COVID-19 pandemic? Reading and mathematics competencies before and after the first pandemic wave. PsyArXiv Working paper. https://doi.org/10.31234/osf.io/pqtgf.

Spitzer, M. W. H. and Musslick, S. (2021). Academic performance of K-12 students in an online-learning environment for mathematics increased during the shutdown of schools in wake of the Covid-19 pandemic. PloS one, 16(8), e0255629.

The Danish Evaluation Institute (2021). Grundskolers erfaringer med nødundervisning under Covid-19 pandemien [Primary schools' experiences with emergency education during the Covid-19 pandemic]. Danmarks Evalueringsinstitut. https://www.eva.dk/grundskole/grundskolers-erfaringer-noedundervisning-undercovid-19-pandemien.

Tomasik, M. J., Helbling, L. A., and Moser, U. (2021). Educational gains of in-person vs. distance learning in primary and secondary schools: A natural experiment during the COVID-19 pandemic school closures in Switzerland. International Journal of Psychology, 56(4), 566-576.

van der Velde, M., Sense, F., Spijkers, R., Meeter, M., and van Rijn, H. (2021). Lockdown learning: Changes in online study activity and performance of Dutch secondary school students during the COVID-19 pandemic. PsyArXiv Working Paper. https://doi.org/10.31234/osf.io/fr2v8.

von Hippel, P. T., Workman, J., and Downey, D. B. (2018). Inequality in reading and math skills forms mainly before kindergarten: A replication, and partial correction, of “Are schools the great equalizer?". Sociology of Education, 91(4), 323-357.

Werner, K. and Woessmann, L. (2021). The Legacy of Covid-19 in Education. CESifo Working Paper 9358. Munich: CESifo.

Zierer, K. (2021). Effects of Pandemic-Related School Closures on Pupils' Performance and Learning in Selected Countries: A Rapid Review. Education Sciences, 11(6), 252. 


\section{Supplementary Materials for: \\ No Evidence of a Major Learning Slide 14 Months into the COVID-19 Pandemic in Denmark}

Supplement A: Pre-analysis plan

p. 2

Supplement B: Descriptive statistics

p. 3

Supplement C: Additional analyses

p. 6

Supplement C1: Estimates of learning development

p. 6

Supplement C2: Math test score results

p. 7

Supplement C3: 2020 results

p. 8

Supplement C4: Placebo results

p. 10

Supplement C5: Within-individual correlations in test scores

p. 11

Supplement C6: Pre-trends by sociodemographic groups

p. 12 


\section{Supplement A: Pre-analysis plan}

We pre-registered our study at the Open Science Framework: https://osf.io/mtajd/. In our preanalysis plan, we described our research hypotheses, data, coding choices, and statistical models. We have only made four minor adjustments to the initial plan in our final paper:

1. In the initial plan, we proposed to use a five-year pre-trend specification (2015-2019) in the main analysis of the learning development in 2021, while using a three-year pre-trend specification (2017-2019) in the analysis of learning development by subgroups. To align the designs of the two analyses, we decided to use a three-year pre-trend in both analyses in the final paper. This decision has very little impact on the results of our main analysis.

2. In the initial plan, we proposed to conduct three sensitivity analyses to ensure the robustness our results: (1) controlling for sibling fixed effects, (2) varying the number of years in the pre-trend specification, and (3) running a placebo analysis of treatment year. In the final paper, we conduct all three analyses and add another four: (1) controlling for prior reading test performance, (2) using a consistent school sample across the measurement period, (3) controlling for timing of the test, and (4) comparing withinindividual correlations in test scores across years.

3. The supplementary analysis of the 2020 test data was not part of our initial pre-analysis plan. We decided to add this analysis as we found the 9 percent school sample to be perfectly representative of the full school population (see Table B5). The addition of the analysis allows us to assess whether developments in reading test scores were strongest after the initial school closure in spring 2020 or the substantially longer school closure in winter 2020/spring 2021.

4. In the initial plan, we proposed to examine whether the development in reading performance differs by gender, ethnicity, family type, parental education, income, and/or employment. In the final paper, we also analyze whether the development in reading performance differs by prior performance, as the question of whether school closures have widened performance gaps has been of interest to both scholars and policy makers (Grewenig et al. 2021). 


\section{Supplement B: Descriptive statistics}

Table B1. Number of observations by grade level and test year.

\begin{tabular}{lcccccccc}
\hline & 2015 & 2016 & 2017 & 2018 & 2019 & 2020 & 2021 & Total \\
\hline Grade 2 & 55,935 & 54,822 & 55,176 & 52,920 & 53,161 & 4,845 & 47,845 & 324,704 \\
Grade 4 & 55,142 & 54,323 & 55,125 & 53,590 & 54,786 & 4,717 & 52,254 & 329,937 \\
Grade 6 & 52,338 & 53,822 & 53,888 & 52,828 & 54,259 & 4,690 & 53,389 & 325,214 \\
Grade 8 & 51,524 & 50,358 & 48,785 & 50,167 & 50,708 & 4,762 & 50,812 & 307,116 \\
Total & 214,939 & 213,325 & 212,974 & 209,505 & 212,914 & 19,014 & 204,300 & $1,286,971$ \\
\hline
\end{tabular}

Table B2. Test completion rate by grade level and test year.

\begin{tabular}{lccccccc}
\hline & 2015 & 2016 & 2017 & 2018 & 2019 & 2020 & 2021 \\
\hline Grade 2 & $98.7 \%$ & $97.9 \%$ & $98.8 \%$ & $98.7 \%$ & $97.9 \%$ & $95.7 \%$ & $96.4 \%$ \\
Grade 4 & $98.7 \%$ & $98.2 \%$ & $98.4 \%$ & $98.7 \%$ & $97.8 \%$ & $96.1 \%$ & $96.6 \%$ \\
Grade 6 & $98.5 \%$ & $98.2 \%$ & $98.5 \%$ & $98.6 \%$ & $97.6 \%$ & $93.9 \%$ & $96.2 \%$ \\
Grade 8 & $97.3 \%$ & $97.0 \%$ & $97.3 \%$ & $97.5 \%$ & $95.9 \%$ & $91.6 \%$ & $94.7 \%$ \\
\hline
\end{tabular}

Table B3. Completion rate of two consecutive tests by grade level and test year.

\begin{tabular}{lccccccc}
\hline & 2015 & 2016 & 2017 & 2018 & 2019 & 2020 & 2021 \\
\hline Grade 2 & - & - & - & - & - & - & - \\
Grade 4 & - & - & $94.0 \%$ & $94.3 \%$ & $93.4 \%$ & $91.9 \%$ & $92.1 \%$ \\
Grade 6 & - & - & $93.7 \%$ & $93.8 \%$ & $92.9 \%$ & $89.6 \%$ & $91.6 \%$ \\
Grade 8 & - & - & $92.3 \%$ & $92.4 \%$ & $91.0 \%$ & $86.4 \%$ & $89.4 \%$ \\
\hline
\end{tabular}

Table B4. Month of test by test year.

\begin{tabular}{lccccccc}
\hline & January & February & March & April & May & June & Total \\
\hline 2015 & $2.5 \%$ & $7.3 \%$ & $23.7 \%$ & $63.8 \%$ & $0.9 \%$ & $1.9 \%$ & $100 \%$ \\
2016 & $0.0 \%$ & $8.0 \%$ & $21.1 \%$ & $68.7 \%$ & $1.2 \%$ & $1.1 \%$ & $100 \%$ \\
2017 & $0.0 \%$ & $5.8 \%$ & $35.0 \%$ & $55.9 \%$ & $1.2 \%$ & $2.1 \%$ & $100 \%$ \\
2018 & $0.0 \%$ & $0.0 \%$ & $23.4 \%$ & $74.1 \%$ & $1.3 \%$ & $1.2 \%$ & $100 \%$ \\
2019 & $0.0 \%$ & $0.0 \%$ & $29.1 \%$ & $68.7 \%$ & $0.8 \%$ & $1.3 \%$ & $100 \%$ \\
2020 & $0.0 \%$ & $0.0 \%$ & $2.2 \%$ & $13.1 \%$ & $27.7 \%$ & $57.0 \%$ & $100 \%$ \\
2021 & $0.0 \%$ & $0.0 \%$ & $5.5 \%$ & $17.7 \%$ & $48.7 \%$ & $28.1 \%$ & $100 \%$ \\
\hline
\end{tabular}


Table B5. Descriptive statistics.

\begin{tabular}{lccccccc}
\hline & 2015 & 2016 & 2017 & 2018 & 2019 & 2020 & 2021 \\
\hline Gender & & & & & & & \\
Girl & $49.0 \%$ & $49.0 \%$ & $48.8 \%$ & $48.8 \%$ & $48.8 \%$ & $49.1 \%$ & $48.9 \%$ \\
Boy & $51.0 \%$ & $51.0 \%$ & $51.2 \%$ & $51.2 \%$ & $51.2 \%$ & $50.9 \%$ & $51.1 \%$ \\
Ethnicity & & & & & & & \\
$\quad$ Danish origin & $89.8 \%$ & $89.6 \%$ & $89.1 \%$ & $88.6 \%$ & $87.9 \%$ & $87.0 \%$ & $87.0 \%$ \\
Children of immigrants & $7.9 \%$ & $7.8 \%$ & $7.7 \%$ & $7.7 \%$ & $7.7 \%$ & $8.2 \%$ & $8.0 \%$ \\
Immigrants & $2.3 \%$ & $2.7 \%$ & $3.2 \%$ & $3.7 \%$ & $4.4 \%$ & $4.8 \%$ & $5.1 \%$ \\
Parental education & & & & & & & \\
College & $45.2 \%$ & $46.2 \%$ & $47.6 \%$ & $48.8 \%$ & $50.0 \%$ & $50.8 \%$ & $52.2 \%$ \\
Less than college & $54.8 \%$ & $53.9 \%$ & $52.4 \%$ & $51.2 \%$ & $50.0 \%$ & $49.2 \%$ & $47.8 \%$ \\
Parental income & & & & & & & \\
Top quartile & $25.0 \%$ & $25.0 \%$ & $25.0 \%$ & $25.0 \%$ & $25.0 \%$ & $25.0 \%$ & $25.0 \%$ \\
3rd quartile & $25.0 \%$ & $25.0 \%$ & $25.0 \%$ & $25.0 \%$ & $25.0 \%$ & $25.0 \%$ & $25.0 \%$ \\
2nd quartile & $25.0 \%$ & $25.0 \%$ & $25.0 \%$ & $25.0 \%$ & $25.0 \%$ & $25.0 \%$ & $25.0 \%$ \\
Bottom quartile & $25.0 \%$ & $25.0 \%$ & $25.0 \%$ & $25.0 \%$ & $25.0 \%$ & $25.0 \%$ & $25.0 \%$ \\
Parental employment & & & & & & & \\
Both parents employed & $81.8 \%$ & $82.1 \%$ & $81.6 \%$ & $81.8 \%$ & $81.9 \%$ & $82.0 \%$ & $82.8 \%$ \\
At least one parent unemployed & $18.2 \%$ & $17.9 \%$ & $18.4 \%$ & $18.2 \%$ & $18.2 \%$ & $18.0 \%$ & $17.2 \%$ \\
Family type & & & & & & & \\
Intact family & $67.4 \%$ & $67.4 \%$ & $67.6 \%$ & $68.0 \%$ & $67.9 \%$ & $68.0 \%$ & $68.1 \%$ \\
Non-intact family & $32.6 \%$ & $32.6 \%$ & $32.4 \%$ & $32.1 \%$ & $32.2 \%$ & $32.0 \%$ & $31.9 \%$ \\
Number of siblings & 1.33 & 1.32 & 1.32 & 1.31 & 1.32 & 1.31 & 1.30 \\
Mean & 0.90 & 0.91 & 0.90 & 0.90 & 0.91 & 0.90 & 0.89 \\
Std. dev. & & & & & & &
\end{tabular}


Table B6. Differences in reading percentile scores in 2019 by sociodemographic groups.

\begin{tabular}{lcccc}
\hline & Grade 2 & Grade 4 & Grade 6 & Grade 8 \\
\hline $\begin{array}{l}\text { Gender (ref: Girl) } \\
\quad \text { Boy }\end{array}$ & -5.81 & -5.74 & -6.28 & -4.57 \\
$\quad$ Ethnicity (ref: Danish origin) & -14.14 & -15.27 & -12.56 & -9.85 \\
$\quad \begin{array}{l}\text { Children of immigrants } \\
\quad \text { Immigrants }\end{array}$ & -20.16 & -23.19 & -22.14 & -20.37 \\
$\quad$ Parental education (ref: College) & -14.87 & -17.42 & -16.61 & -15.75 \\
$\quad$ Less than college & & & & \\
Parental income (ref: Top quartile) & -6.37 & -7.44 & -6.95 & -7.79 \\
$\quad$ 3rd quartile & -12.88 & -14.90 & -14.45 & -14.94 \\
$\quad$ 2nd quartile & -20.16 & -23.05 & -22.54 & -21.21 \\
$\quad$ Bottom quartile & & & & \\
Parental employment (ref: Both parents employed) & & & & \\
$\quad$ At least one parent unemployed & -13.34 & -14.50 & -13.04 & -11.88 \\
Family type (ref: Intact family) & & & & \\
$\quad$ Non-intact family & -6.41 & -6.82 & -6.54 & -5.66 \\
\hline
\end{tabular}




\section{Supplement C: Additional analyses}

\section{Supplement C1: Estimates of learning development}

Table C1.1. Estimates of the 2021 learning development in reading by grade level.

\begin{tabular}{lcccc}
\hline & Grade 2 & Grade 4 & Grade 6 & Grade 8 \\
\hline Baseline & $4.73 * * *$ & $5.31 * * *$ & $3.04 * * *$ & $-2.95 * * *$ \\
& $(-0.31)$ & $(-0.30)$ & $(-0.30)$ & $(-0.32)$ \\
All controls & $4.77 * * *$ & $5.14 * * *$ & $2.99 * * *$ & $-2.79 * * *$ \\
& $(-0.29)$ & $(-0.28)$ & $(-0.28)$ & $(-0.30)$ \\
Prior performance & - & $5.09 * * *$ & $2.87 * * *$ & $-3.08 * * *$ \\
& $(-)$ & $(-0.22)$ & $(-0.21)$ & $(-0.24)$ \\
Sibling FE & $5.64 * * *$ & $6.45 * * *$ & $3.34 * * *$ & $-3.52 * * *$ \\
& $(-0.55)$ & $(-0.51)$ & $(-0.51)$ & $(-0.59)$ \\
Consistent schools & $4.71 * * *$ & $5.13 * * *$ & $2.90 * * *$ & $-2.79 * * *$ \\
& $(-0.29)$ & $(-0.28)$ & $(-0.28)$ & $(-0.30)$ \\
Month of test & $3.40^{* * *}$ & $5.05 * * *$ & $3.16^{* * *}$ & $-1.77 * * *$ \\
& $(-0.35)$ & $(-0.32)$ & $(-0.36)$ & $(-0.36)$ \\
Two-year pre-trend & $5.95 * * *$ & $6.06 * * *$ & $2.83 * * *$ & $-1.70 * * *$ \\
& $(-0.44)$ & $(-0.43)$ & $(-0.43)$ & $(-0.45)$ \\
No pre-trend & $4.19 * * *$ & $2.72 * * *$ & $-0.69 * * *$ & $-3.32 * * *$ \\
& $(-0.17)$ & $(-0.16)$ & $(-0.16)$ & $(-0.18)$ \\
\hline
\end{tabular}

Note: Standard errors in parenthesis. ${ }^{*} \mathrm{p}<0.05,{ }^{* *} \mathrm{p}<0.01,{ }^{* * *} \mathrm{p}<0.001$. 


\section{Supplement C2: Math test score results}

Figure C2.1. Development in math test scores by grade level.

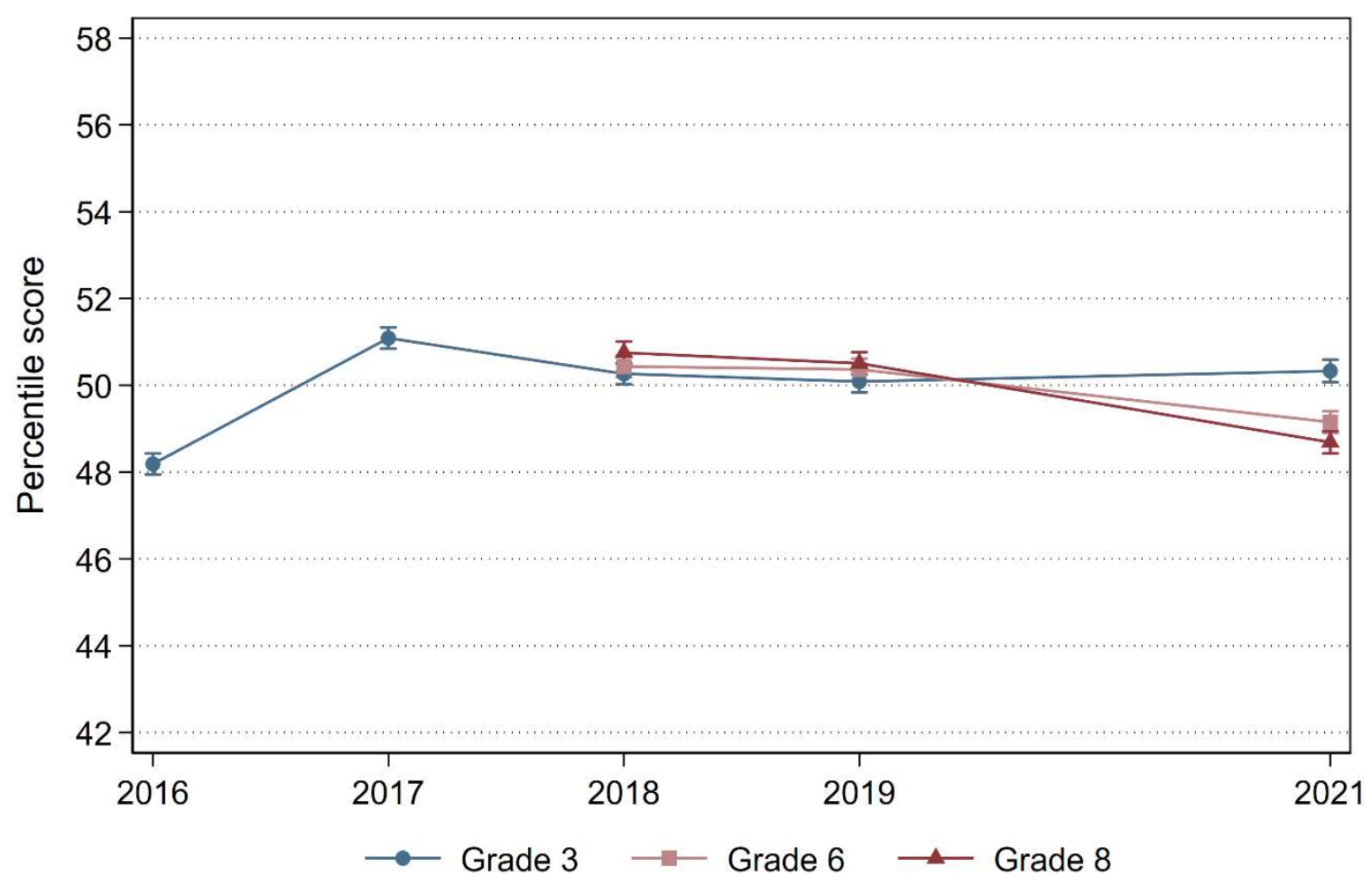

Figure C2.2. Estimates of the 2021 learning development in math by grade level.
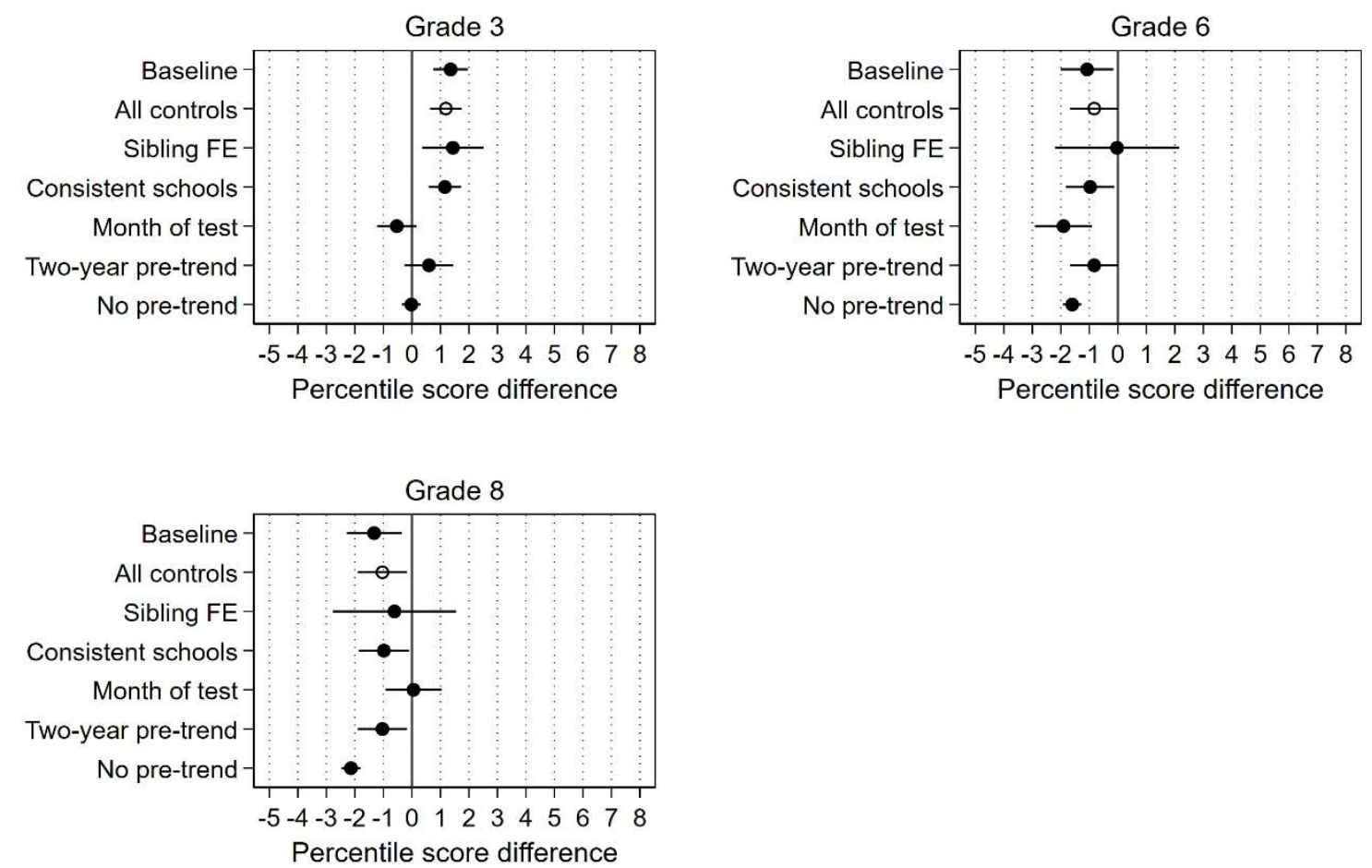


\section{Supplement C3: 2020 results}

Figure C3.1. Development in reading test scores by grade level, 2020 school sample.

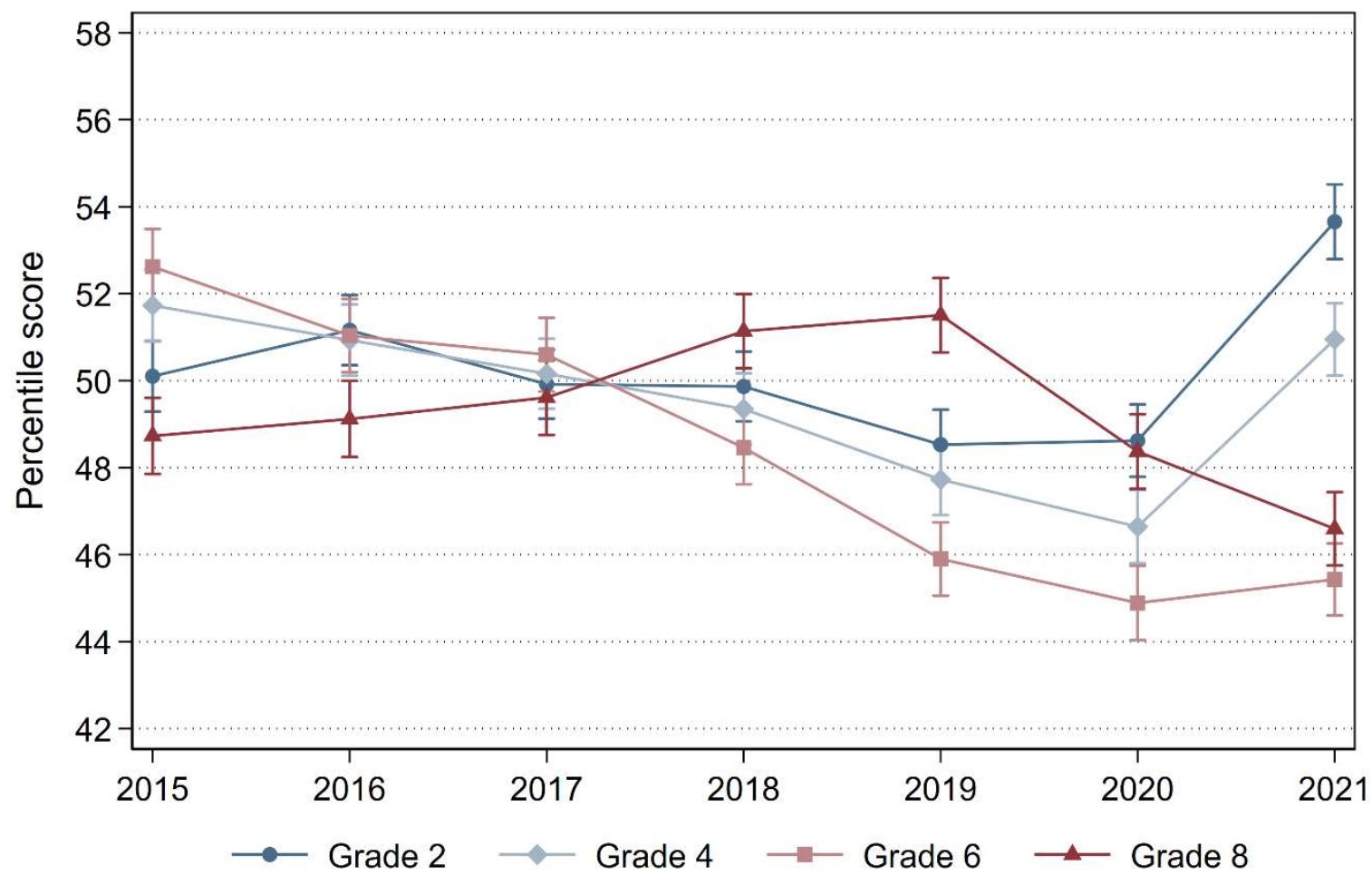

Figure C3.2. Estimates of the 2020 learning development in reading by grade level.
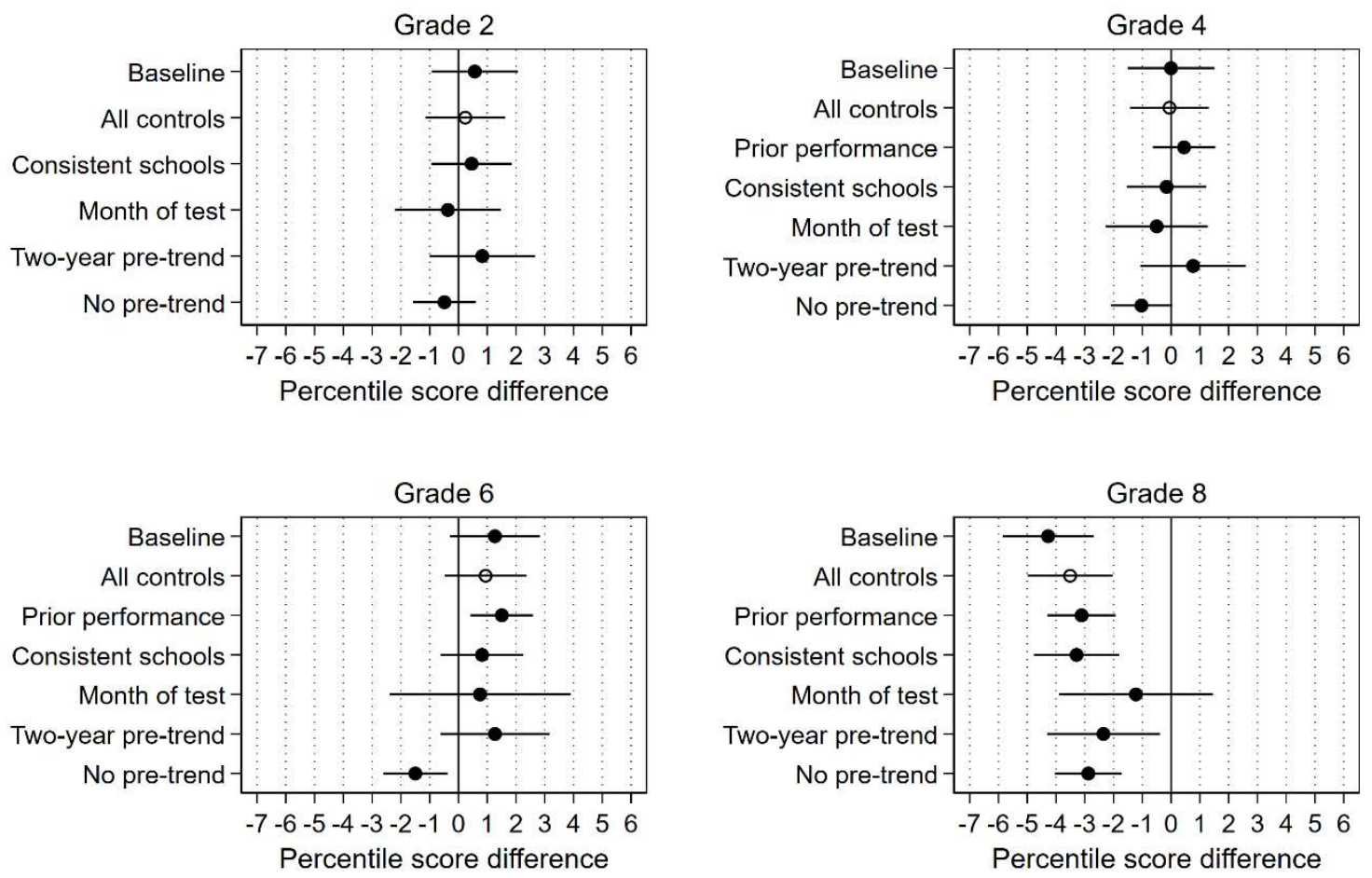
Table C3.1. Differences in the 2020 learning development in reading by sociodemographic groups.

\begin{tabular}{|c|c|c|c|c|}
\hline & $\begin{array}{l}\text { Grade } \\
(2-) 4\end{array}$ & $\begin{array}{c}\text { Grade } \\
(4-) 6\end{array}$ & $\begin{array}{c}\text { Grade } \\
(6-) 8\end{array}$ & Pooled \\
\hline \multicolumn{5}{|l|}{ Gender (ref: Girl) } \\
\hline Boy & $\begin{array}{l}-1.76 \\
(1.25)\end{array}$ & $\begin{array}{l}-1.19 \\
(1.21)\end{array}$ & $\begin{array}{c}-0.73 \\
(1.33)\end{array}$ & $\begin{array}{l}-1.23 \\
(0.73)\end{array}$ \\
\hline \multicolumn{5}{|l|}{ Ethnicity (ref: Danish origin) } \\
\hline Children of immigrants & $\begin{array}{c}2.09 \\
(2.16)\end{array}$ & $\begin{array}{l}-0.77 \\
(2.46)\end{array}$ & $\begin{array}{c}-3.85 \\
(2.58)\end{array}$ & $\begin{array}{l}-1.22 \\
(1.41)\end{array}$ \\
\hline Immigrants & $\begin{array}{l}-0.81 \\
(3.40)\end{array}$ & $\begin{array}{c}2.08 \\
(3.65)\end{array}$ & $\begin{array}{l}-4.04 \\
(4.66)\end{array}$ & $\begin{array}{c}-0.72 \\
(2.24)\end{array}$ \\
\hline \multicolumn{5}{|l|}{ Parental education (ref: College) } \\
\hline Less than college & $\begin{array}{c}0.66 \\
(1.25)\end{array}$ & $\begin{array}{c}1.40 \\
(1.21)\end{array}$ & $\begin{array}{l}-1.66 \\
(1.33)\end{array}$ & $\begin{array}{c}0.21 \\
(0.73)\end{array}$ \\
\hline \multicolumn{5}{|l|}{ Parental income (ref: Top quartile) } \\
\hline 3rd quartile & $\begin{array}{c}1.16 \\
(1.68)\end{array}$ & $\begin{array}{l}-1.56 \\
(1.65)\end{array}$ & $\begin{array}{c}0.49 \\
(1.77)\end{array}$ & $\begin{array}{c}0.26 \\
(0.98)\end{array}$ \\
\hline 2nd quartile & $\begin{array}{c}3.10 \\
(1.74)\end{array}$ & $\begin{array}{c}2.13 \\
(1.65)\end{array}$ & $\begin{array}{l}-1.56 \\
(1.80)\end{array}$ & $\begin{array}{c}1.50 \\
(1.00)\end{array}$ \\
\hline Bottom quartile & $\begin{array}{c}0.60 \\
(1.73)\end{array}$ & $\begin{array}{c}0.17 \\
(1.77)\end{array}$ & $\begin{array}{l}-4.00 * \\
(1.92)\end{array}$ & $\begin{array}{l}-0.78 \\
(1.05)\end{array}$ \\
\hline \multicolumn{5}{|c|}{ Parental employment (ref: Both parents employed) } \\
\hline At least one parent unemployed & $\begin{array}{l}3.87^{*} \\
(1.72)\end{array}$ & $\begin{array}{c}1.27 \\
(1.66)\end{array}$ & $\begin{array}{l}-1.43 \\
(1.77)\end{array}$ & $\begin{array}{c}1.23 \\
(1.00)\end{array}$ \\
\hline \multicolumn{5}{|l|}{ Family type (ref: Intact family) } \\
\hline Non-intact family & $\begin{array}{l}-0.61 \\
(1.39)\end{array}$ & $\begin{array}{c}-0.63 \\
(1.29)\end{array}$ & $\begin{array}{l}-2.73 \\
(1.41)\end{array}$ & $\begin{array}{l}-1.38 \\
(0.79)\end{array}$ \\
\hline \multicolumn{5}{|l|}{ Prior performance (ref: Top quartile) } \\
\hline 3rd quartile & $\begin{array}{l}-1.47 \\
(1.59)\end{array}$ & $\begin{array}{c}0.58 \\
(1.52)\end{array}$ & $\begin{array}{l}-1.03 \\
(1.63)\end{array}$ & $\begin{array}{c}-0.64 \\
(0.91)\end{array}$ \\
\hline 2nd quartile & $\begin{array}{l}-0.06 \\
(1.57)\end{array}$ & $\begin{array}{c}1.05 \\
(1.55)\end{array}$ & $\begin{array}{c}2.14 \\
(1.70)\end{array}$ & $\begin{array}{c}1.13 \\
(0.93)\end{array}$ \\
\hline Bottom quartile & $\begin{array}{l}-0.24 \\
(1.54)\end{array}$ & $\begin{array}{c}1.24 \\
(1.48)\end{array}$ & $\begin{array}{c}0.29 \\
(1.61)\end{array}$ & $\begin{array}{c}0.45 \\
(0.89)\end{array}$ \\
\hline
\end{tabular}




\section{Supplement C4: Placebo results}

Table C4.1. Placebo test. Estimates of learning developments by placebo assignment year, grade level, and three different pre-trend periods.

\begin{tabular}{|c|c|c|c|c|c|}
\hline & 2015 & 2016 & 2017 & 2018 & 2019 \\
\hline \multicolumn{6}{|l|}{ Grade 2} \\
\hline \multirow[t]{2}{*}{$2015-2018$} & 0.18 & -0.05 & -0.12 & 0.23 & - \\
\hline & $(0.21)$ & $(0.14)$ & $(0.14)$ & $(0.21)$ & $(-)$ \\
\hline \multirow[t]{2}{*}{$2016-2019$} & - & $-0.52 *$ & 0.06 & $0.56 * * *$ & $-0.92 * * *$ \\
\hline & $(-)$ & $(0.21)$ & $(0.14)$ & $(0.14)$ & $(0.21)$ \\
\hline \multirow[t]{2}{*}{$2015-2019$} & -0.25 & -0.06 & 0.10 & $0.55 * * *$ & $-0.79 * * *$ \\
\hline & $(0.18)$ & $(0.14)$ & $(0.13)$ & $(0.14)$ & $(0.18)$ \\
\hline \multicolumn{6}{|l|}{ Grade 4} \\
\hline \multirow[t]{2}{*}{$2015-2018$} & $1.16 * * *$ & $-0.68 * * *$ & -0.13 & $0.73 * * *$ & - \\
\hline & $(0.21)$ & $(0.14)$ & $(0.14)$ & $(0.21)$ & $(-)$ \\
\hline \multirow[t]{2}{*}{ 2016-2019 } & - & $-0.55 * *$ & 0.14 & $0.43 * *$ & $-0.78 * * *$ \\
\hline & $(-)$ & $(0.21)$ & $(0.14)$ & $(0.14)$ & $(0.21)$ \\
\hline \multirow[t]{2}{*}{$2015-2019$} & $0.74 * * *$ & $-0.67 * * *$ & -0.05 & $0.43 * *$ & -0.22 \\
\hline & $(0.18)$ & $(0.14)$ & $(0.13)$ & $(0.14)$ & $(0.18)$ \\
\hline \multicolumn{6}{|l|}{ Grade 6} \\
\hline \multirow[t]{2}{*}{$2015-2018$} & -0.13 & -0.14 & $0.44 * *$ & $-0.58 * *$ & - \\
\hline & $(0.21)$ & $(0.14)$ & $(0.14)$ & $(0.21)$ & $(-)$ \\
\hline \multirow[t]{2}{*}{ 2016-2019 } & - & $-0.80 * * *$ & $0.48 * * *$ & 0.06 & $-0.47 *$ \\
\hline & $(-)$ & $(0.21)$ & $(0.14)$ & $(0.14)$ & $(0.21)$ \\
\hline \multirow[t]{2}{*}{$2015-2019$} & $-0.39 *$ & -0.13 & $0.52 * * *$ & 0.07 & $-0.56 * *$ \\
\hline & $(0.18)$ & $(0.14)$ & $(0.13)$ & $(0.14)$ & $(0.18)$ \\
\hline \multicolumn{6}{|l|}{ Grade 8} \\
\hline \multirow[t]{2}{*}{$2015-2018$} & $0.74 * * *$ & $-0.54 * * *$ & 0.14 & 0.22 & - \\
\hline & $(0.22)$ & $(0.14)$ & $(0.15)$ & $(0.22)$ & $(-)$ \\
\hline \multirow[t]{2}{*}{ 2016-2019 } & - & $-1.18 * * *$ & $0.42 * *$ & $0.68 * * *$ & $-1.38 * * *$ \\
\hline & $(-)$ & $(0.22)$ & $(0.15)$ & $(0.14)$ & $(0.22)$ \\
\hline \multirow[t]{2}{*}{ 2015-2019 } & 0.03 & $-0.52 * * *$ & $0.37 * *$ & $0.68 * * *$ & $-1.02 * * *$ \\
\hline & $(0.19)$ & $(0.14)$ & $(0.14)$ & $(0.14)$ & $(0.19)$ \\
\hline
\end{tabular}




\section{Supplement C5: Within-individual correlations in test scores}

Table C5.1. Spearman rank correlations between reading test scores separated by two years by grade level and test years.

\begin{tabular}{lccc}
\hline & Grade 2 to 4 & Grade 4 to 6 & Grade 6 to 8 \\
\hline 2019 to 2021 & 0.680 & 0.725 & 0.656 \\
2017 to 2019 & 0.674 & 0.727 & 0.671 \\
2016 to 2018 & 0.677 & 0.739 & 0.699 \\
2015 to 2017 & 0.681 & 0.739 & 0.708 \\
\hline
\end{tabular}




\section{Supplement C6: Pre-trends by sociodemographic groups}

Figure C6.1. Difference in the development in reading test scores between grades 2 and 4 by sociodemographic groups.
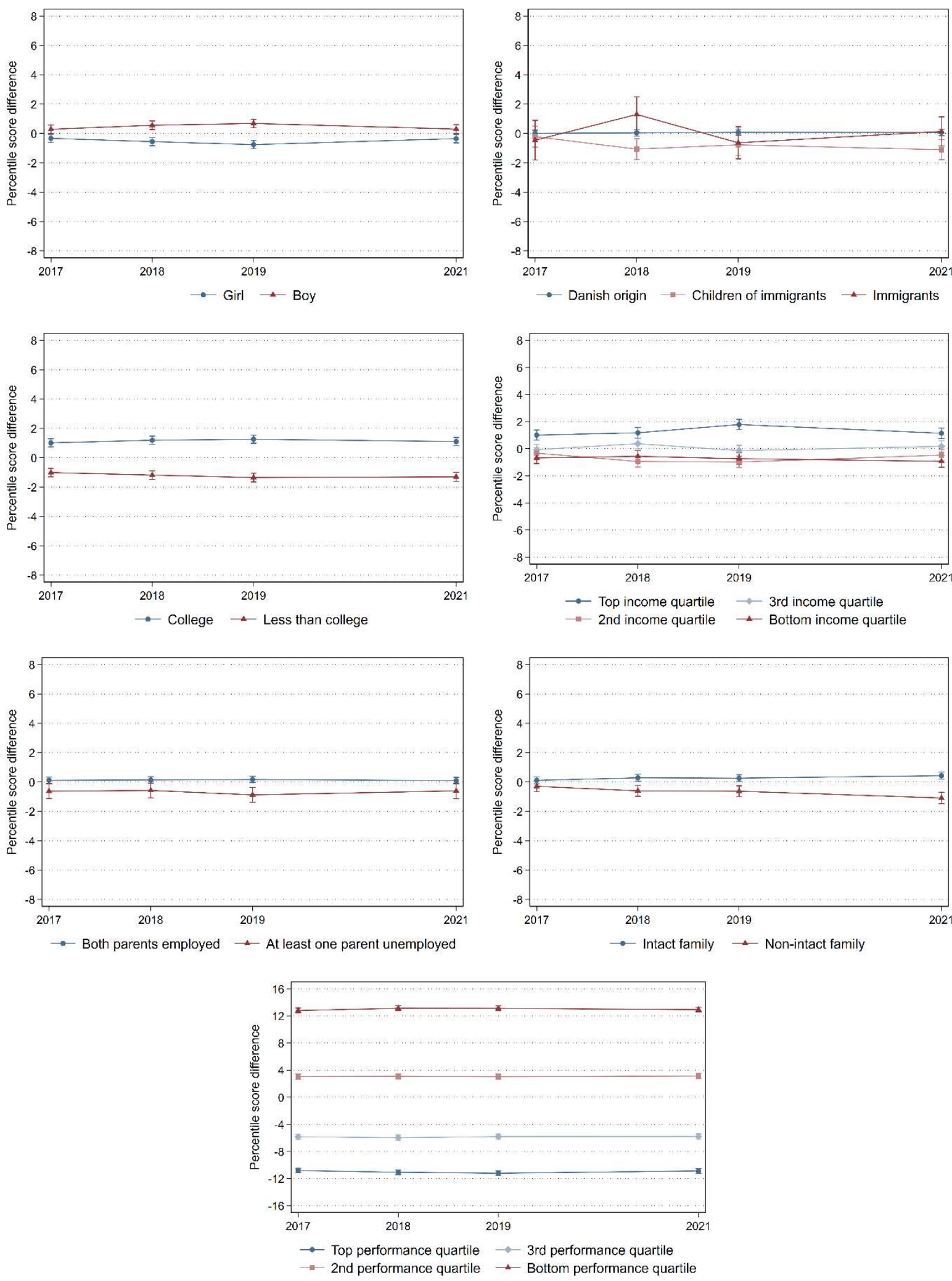
Figure C6.2. Difference in the development in reading test scores between grades 4 and 6 by sociodemographic groups.
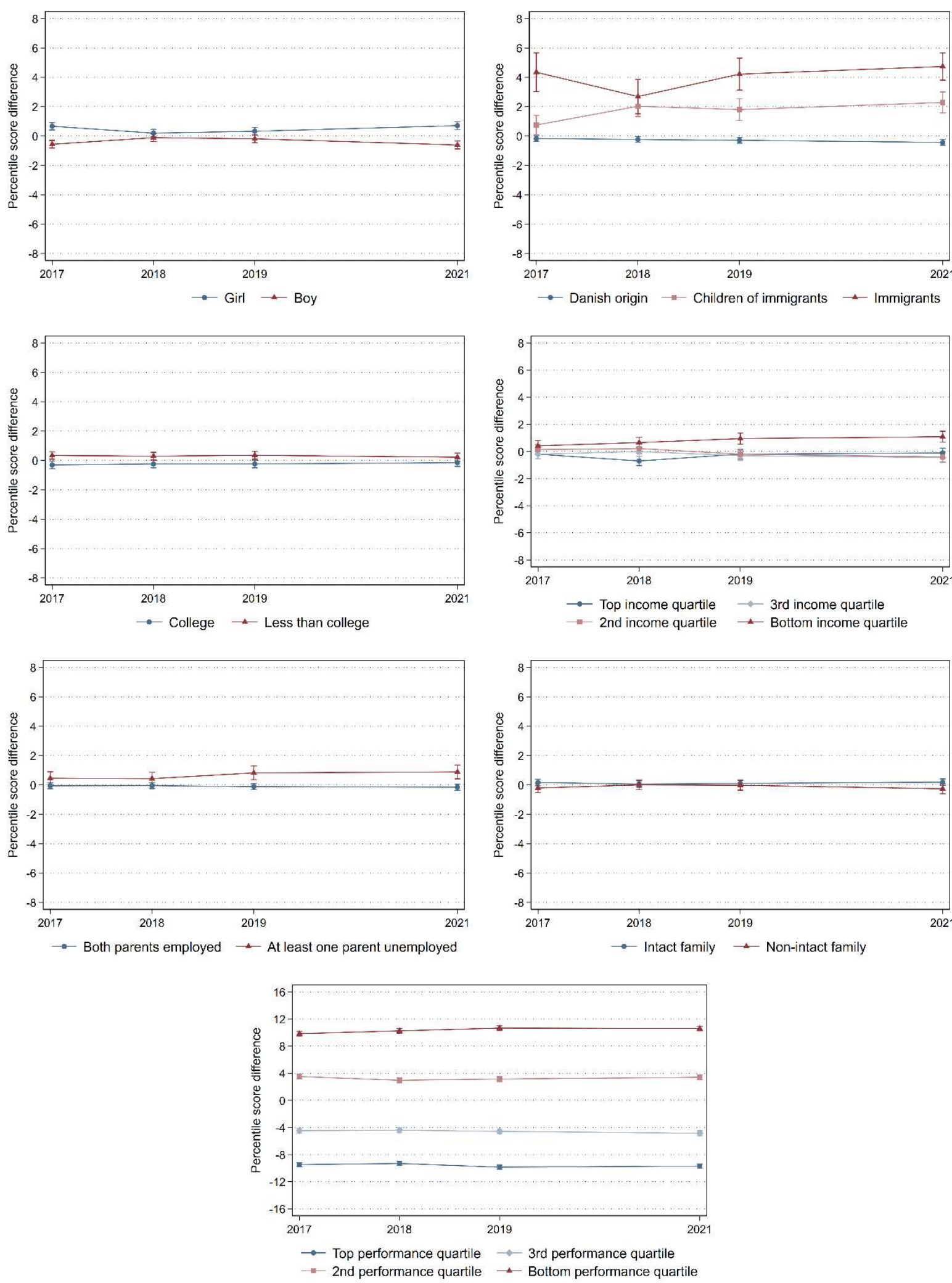
Figure C6.3. Difference in the development in reading test scores between grades 6 and 8 by sociodemographic groups.
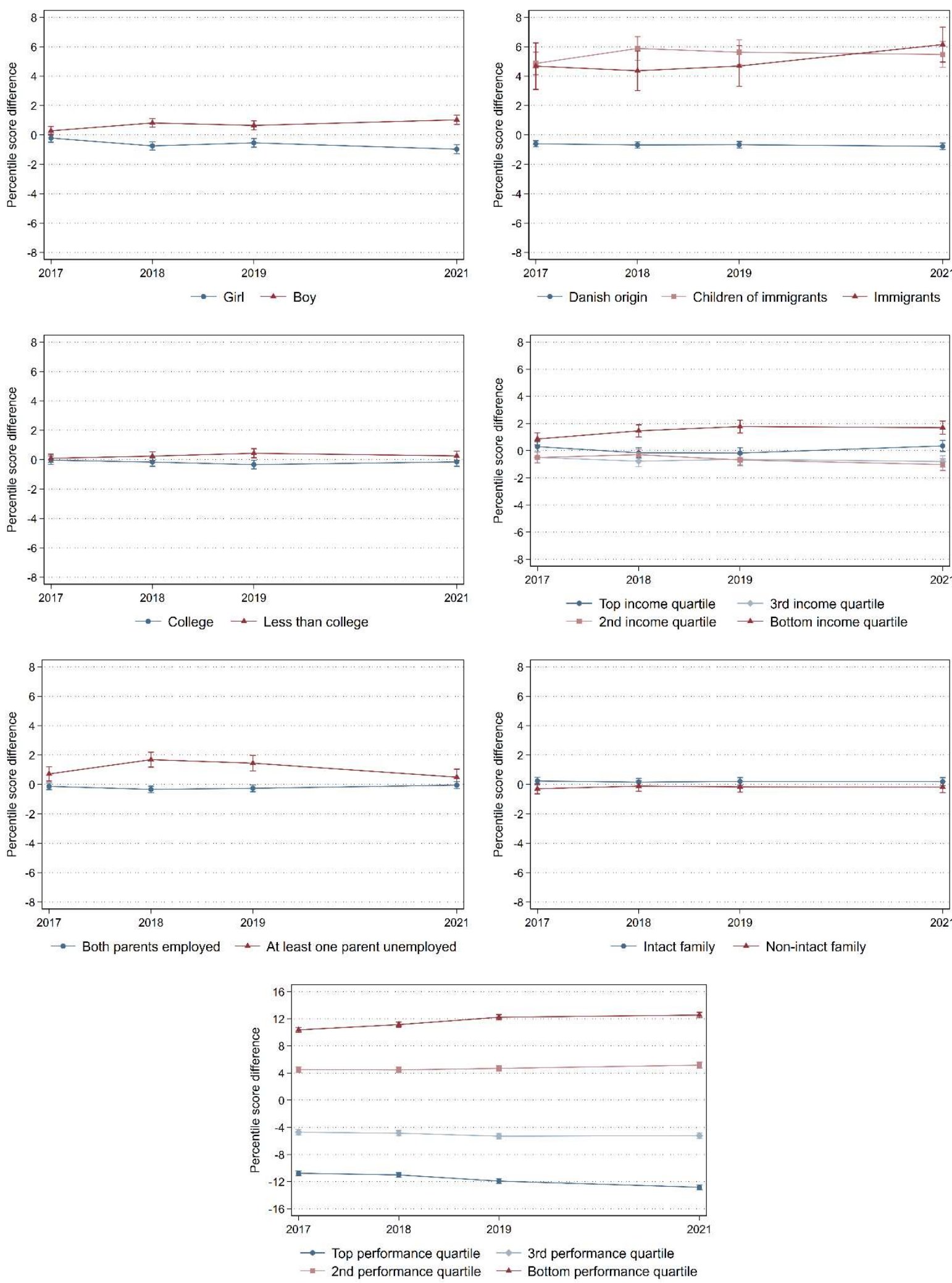